\title{
Birleşmiş Milletler Üyeliğinden Çekilmeye Dair Muhtemel Prosedürlerin İncelenmesi
}

Scrutinizing Possible Procedures by which States Withdraw from the United Nations

\section{Mehmet Halil Mustafa BEKTAŞ}

Dr. Öğr. Üyesi, Uluslararası İlişkiler Bölümü, Bursa Uludağ Üniversitesi

\section{Bu makaleye atıf için}

Bektaş, Mehmet Halil Mustafa, "Birleşmiş Milletler Üyeliğinden Çekilmeye Dair Muhtemel Prosedürlerin İncelenmesi”, Uluslararası İlişkiler, Cilt 16, Say1 61, 2019, s. 39-54, DOI: $\underline{10.33458 / \text { uidergisi.541525 }}$

Makaleye Erişim İçin: https://dx.doi.org/10.33458/uidergisi.541525

Makale Gönderim: 03 Temmuz 2018

Basım Tarihi: 01 Mart 2019 


\title{
Birleşmiş Milletler Üyeliğinden Çekilmeye Dair Muhtemel Prosedürlerin İncelenmesi
}

\author{
Mehmet Halil Mustafa BEKTAŞ \\ Dr. Öğr. Üyesi, Uluslararası İlişkiler Bölümü, İİBF, Bursa Uludağ Üniversitesi, Bursa. \\ E-posta:mhmbektas@uludag.edu.tr
}

\begin{abstract}
ÖZET
Devletler bir uluslararası örgütle üyelik müzakerelerini yürütürken, üyelikten çekilme konusu üzerinde pek durmazlar. Küresel öneme sahip olan Birleşmiş Milletler (BM) de bu örgütlerden bir tanesidir. Ancak kasti veya gayrikasti olarak göz ardı edilen bu konu, bir devletin üyelikten çekilmesi mevzubahis olduğunda, üyeliğe giriş kadar önemli olabilmektedir. BM Şartında Milletler Cemiyeti Misakının aksine üyelikten çekilme ile ilgili bir düzenleme bulunmamaktadır. Peki, BM üyeliğinden çekilme söz konusu olduğunda nasıl bir prosedür izlenecektir? Mevcut çalışma, bu soruya cevap verebilmek için, San Francisco Konferansı Komisyonu tarafından konu ile ilgili önerilen taslağı, Endonezya örneğini ve Viyana Andlaşmalar Hukuku Sözleşmesi’nin ilgili maddelerini incelemiştir. Böylelikle, anılan üç temel enstrümanın muhtemel bir üyelikten çekilme durumunda nasıl bir yol izlenebileceğine ilişkin aydınlatıcı bir prosedür sunma özelliğine haiz olup olmadıkları irdelenmiştir. Türkçe literatürde konuyla ilgili çalışma olmaması nedeniyle, bu çalışma önemli bir boşluğu da dolduracaktır.
\end{abstract}

Anahtar Kelimeler: BM Şartı, Üyelikten Çekilme, San Francisco Konferansı Çalışmaları, Viyana Sözleşmesi

\section{Scrutinizing Possible Procedures by which States Withdraw from the United Nations}

\begin{abstract}
A state rarely considers leaving an international organization when negotiating the conditions of its entry. Among such organizations is the United Nations (UN), an institution of obvious global importance. The issue of withdrawal, neglected though it often is (whether deliberately or unintentionally), could however be equally as significant as that of entry. By contrast with the Covenant of the League of Nations, the UN Charter makes no provision for withdrawal. The procedure to be followed should a state request to withdraw is therefore left uncertain. The current study therefore examines three primary instruments: the proposal of the Committee of the San Francisco Conference, the Indonesian example and the inclusion of the relevant provisions of the Vienna Convention on the Law of Treaties. The study aims to determine whether these instruments provide an explicit procedure for withdrawal from the UN. The current study contributes to the Turkish literature by providing insight into this largely ignored topic.
\end{abstract}

Keywords: UN Charter, withdrawal, San Fransisco Conference Proposals, Vienna Convention 


\section{Giriş}

Eski bir özdeyiş der ki: 'İnsanlar düğün öncesi boşanmaktan bahsetmekten hoşlanmazlar.' Bu özdeyiş, aslında devletlerin uluslararası andlaşmalara taraf olurken genelde ne yaptıklarını açıklıyor diyebiliriz. ${ }^{1}$ 1969 Viyana Andlaşmalar Hukuku Sözleşmesi'nin (VAHS) dibacesinde, her egemen devletin bir andlaşmaya taraf olup olmamak konusunda özgür olduğu ifade edilmiştir. Mamafih, uluslararası andlaşmaların ekseriyetinde, devletlerin üyeliklerini sona erdirmelerine dair hükümlerin genellikle kasti ya da gayrikasti surette zımnen gizlendiği görülmektedir. ${ }^{2} \mathrm{Bu}$ durumun mevcudiyeti (lacuna), devletlerin andlaşmadan çekilmelerini nispi olarak zorlaştırmakla beraber daha çok konuya ilişkin iltibasa ve ihtilafa sebep olmaktadır.

Üyelikten çekilme hükümlerinin kasti ya da gayrikasti suretle göz ardı edilmesi veya gizlenmesi muhtelif nedenlerden kaynaklanabiliyor. İlk olarak, bazen devletlerin yeni bir örgüte dâhil olarak elde edecekleri büyük beklentilerinin olması ve çekilme hususunun da bu beklentilerinin gölgesinde kalması söz konusu olabilmektedir. İkinci olarak, bazı devletler, üyeliklerini istedikleri zaman sonlandırmayı egemenliklerinden kaynaklanan bir hak olarak görmeleri nedeniyle, üyelikten çekilme hükümlerinin düzenlenip düzenlenmemesi hususunu önemsememektedirler. Bunlara ek olarak, örgütün kurucuları, devletlerin üyelikten doğan vecibelerden, üyelikten çıkarak kaçınmalarını önlemek maksadıyla üyelikten çekilmeye dair hükümleri hariç tutmayı bir önlem aracı olarak kullanabilmektedirler. Bununla ilintili olarak, insanlık için önemli olduğu varsayılan 'sınırsız uzun süreli bir örgüt' kurma amacı söz konusu olduğunda, çekilmeye müsaade eden düzenlemeler kasti olarak sözleşmeye eklenmeyebilmektedir.

Küresel öneme sahip olan Birleşmiş Milletler (BM) Şartı da bu andlaşmalardan bir tanesidir. Filhakika, selefi olan Milletler Cemiyeti’nin (MC) aksine, BM Şartı'nda bir üye devletin kendi rızasıyla çekilmesine dair bir düzenleme bulunmamaktadır. Mevzuya ilişkin BM’nin kuruluş dönemine ait kaynaklar incelendiğinde, böyle bir düzenlemenin BM Şartı’na kasti olarak -MC'nin zafiyetine düşmemek maksadıyla- eklenmediği görülmektedir. Diğer bir deyişle, BM üyelerini üyelikten çekilmekten caydırıcı veya bunların üyelikten çekilmesini zorlaştırıcı bir tedbir olarak düşünülmüştür. Ancak, 'çekilme' maddesinin BM Şartı́na eklenmemesinin, üyelikten çekilmeye dair vakalar söz konusu olduğunda BM açısından sorunlara gebe olduğunu söyleyebiliriz. Çalışma, öncelikle herhangi bir BM üyesinin üyelikten çekilmeyi istemesi halinde nasıl bir prosedür izlenebileceğine dair bir yöntem önermektedir. Bu bağlamda, mevcut çalışmada, BM’ye ilişkin hazırlık çalışmaları (travaux préparatoires) incelenecek, ikinci olarak, VAHS (1969) açısından konu ele alınacak ve son olarak Endonezya somut örneği değerlendirilecektir.

Sonuç olarak, gerek BM Şartı gerekse diğer uluslararası kaynakların, BM üyeliğinden çekilmeye dair açıklayıcı ve uygulanabilir bir prosedür sunmaktan uzak olduğu tespit edilmiştir. Bununla beraber, üyelikten çekilmeye dair prosedürümüphem bırakarak, üye devletlerinüyelikten ayrılmalarınıgüçleştirme amacı da sorgulandığında, BM Şartı nezdinde 'çekilme' mevzuatının eksikliğinin aslında üyeler üzerinde pek de caydırıcı bir etkisi olmadığı ve olmayacağı, daha çok konuya ilişkin uyuşmazlıklara açık olduğu vurgulanmıştır. Konuya dair oluşabilecek uyuşmazlıkları aşmak için başvurulabilecek çözümlemenin ve bunun uygulanabilirliğinin ne olabileceği açıklanmaya çalışılacaktır.

1 Laurence R. Helfer, “Terminating Treaties”, Duncan B. Hollis (Der.), The Oxford Guide to Treaties, Oxford University Press, 2012, s.634.

2 Ibid. 


\section{BM Üyeliğine İlişkin Mevzuat ve Uygulama}

BM üyeliğine dair konuları genel olarak üç başlık altında toplayabiliriz:

i. Üyeliğe giriş,

ii. Üyeliğin askıya alınması veya üyelikten çıkarılma,

iii. Üyelikten çekilme.

Üyelikten çekilme konusu hariç, gerek üyeliğe giriş gerekse üyeliğin askıya alınması veya üyelikten çıkarılma konuları BM Şartı’nda sarih bir şekilde düzenlenmiştir. Filhakika, bir devletin BM’ye üye olabilmesi için gerekli kaideler BM Şartı 4. maddesinde açıkça belirtilmiştir:

1. İşbu Andlaşmanın getirdiği yükümlülükleri kabul eden ve bunları yerine getirme konusunda yetenekli ve istekli olduklarına örgütçe hükmedilen tüm diğer barışsever devletler Birleşmiş Milletlere üye olabilirler.

2. Bu koşullara uyan her devletin Birleşmiş Milletler üyeliğine kabulü, Güvenlik Konseyi’nin tavsiyesi üzerine Genel Kurul kararı ile olur.

Bu konuda izlenecek usul şöyledir: Öncelikle üye olmak isteyen devlet, BM Genel Sekreterliği’ne başvurusunu yapar. BM Güvenlik Konseyi başvuruyu inceler ve daimi üyelerin olumsuz oy kullanmaması şartıyla, Konsey'de 9 üyenin olumlu oyuyla başvuru kabul edilir. Nihai aşamada, BM Şartı́nın 18. maddesinin 2. fikrası gereği üye olmak isteyen devletin başvurusu Genel Kurul'da oylamaya sunulur ve $2 / 3$ çoğunluğun olumlu oy kullanması ile söz konusu devlet üyeliğe kabul edilir.

Üyeliğin askıya alınması veya üyelikten çıkarılma konuları da BM Şartı'nın 5. ve 6. maddelerinde şöyle düzenlenmiştir:

5. Güvenlik Konseyi tarafından aleyhinde bir önleyici ya da zorlayıcı önlem alınmış bulunan bir Birleşmiş Milletler üyesi, üyelik sıfatından doğan hak ve ayrıcalıklarını kullanmaktan, Güvenlik Konseyi’nin tavsiyesi üzerine Genel Kurul tarafından alıkonabilir. Güvenlik Konseyi bu hak ve ayrıcalıkların kullanılmasına yeniden izin verebilir.

6. İşbu Andlaşma’da belirtilen ilkeleri ısrarla çiğneyen bir Birleşmiş Milletler üyesi, Güvenlik Konseyi’nin tavsiyesi üzerine Genel Kurul tarafından örgütten çıarılabilir.

$\mathrm{Bu}$ maddelerin uygulanmasında genel olarak bir zorluk yaşanmamaktadır. Mamafih, üyeliğe girişte Güvenlik Konseyi daimi üyelerinin olumlu oyu arandığı için, bazen daimi üyelerin uyuşmazlıkları söz konusu olabilmektedir. Bu bağlamda, gerek veto engelinden dolayı gerekse yeterli sayıda devlet tarafından tanınmamasından dolayı ${ }^{3}$ üye olamayan Tayvan, Kosova, KKTC, Güney Osetya ve Abhazya gibi, devlet niteliği uluslararası hukuk açısından tartışmalı da olsa, bazı birimlerden söz etmek mümkündür.

Bunlara ilaveten, bazen bazı devletler BM'ye üye olamayı veya iradi olarak üye olmayıp 'gözlemci üye' statüsü elde edebildikleri gibi, BM’nin UNESCO gibi bazı uzman kuruluşlarına da üye olabiliyorlar. Kendine özgü (sui generis) yapısı olan 'gözlemci üyelik' statüsü için de BM Şartı́nda herhangi bir düzenleme bulunmamakta ve bu statü teamüle dayanmaktadır. Gözlemci üyelik statüsü verilmesi için Güvenlik Konseyi’nin daimi üyelerinin olumlu oyu aranmaz, Genel Kurul bu konuda

3 Üye olmak isteyen devletin, Genel Kurul'un 2/3 çoğunluk ile kabul edilmesi şartı arandığı için, yeterli üye tarafından tanınmaması da engel olabilmektedir. 
yetkili mercidir. ${ }^{4}$ Gözlemci üyelik statüsünü ilk olarak İsviçre 1948 yılında elde etmiş ve bu statüsünü 54 yıl sürdürdükten sonra 2002 yılında tam üyeliğe geçmiştir. İsviçre'nin bu durumu, benimsemiş olduğu sürekli tarafsızlık statüsüne ters düşmeme kaygısından ileri gelse de tam üyeliğe herhangi bir dış engel olmadan geçebilme imkânı varken uzun bir süre bu statüde kalmıştır. Mamafih, Filistin’in tam üyelik statüsü elde etmesi Güvenlik Konseyi’ndeki veto engelinden dolayı gerçekleşmemiş, Filistin, 2012 yılında gözlemci üye statüsü elde edebilmiştir.

Üyeliğin askıya alınması veya üyelikten çıkarılma konuları açıç̧a belirtilmiş olsa da, bu prosedüre henüz başvurulmamıştır. Sadece Güney Afrika'da 1948 ile 1994 yılları arasındaki 'apartheid rejimi’ nedeniyle, Güney Afrika’nın üyelikten çıkarılması için gündeme getirilmiş; ancak $A B D$, İngiltere ve Fransa'nın vetolarıyla 1974 yılında bunun uygulanmasına izin vermemeleri üzerine, sadece BM Genel Kurulu tarafından Güney Afrika’nın toplantılara katılımı 1994 yılına kadar engellenmiştir. Ancak, İsrail gibi bazı 'ihlalci devletler' hakkında -uygulamadıkları birçok Güvenlik Konseyi kararı bulunmasına rağmen- üyeliğin askıya alınması veya üyelikten çıkarılma gibi herhangi bir girişim söz konusu olmamıştır.

Tüm bunlara ek olarak, BM üyeliğine geri kabul (readmission) bazı durumlarda söz konusu olabilmektedir. Geri kabul prosedürüne, gerek üyelikten çıkarılma veya çekilmeden dolayı üyeliğe tekrar dönmek isteyen devletler tarafından, gerekse başka bir devletle birleşip uluslararası hukuk süjesi olma özelliğini kaybetmesiyle üyeliği sona eren ve daha sonra birleştiği devletten ayrılarak uluslararası kişiliğini tekrar kazanmasının ardından üyeliğe dönmek isteyen devletler tarafından başvurulmaktadır. ${ }^{6}$ Üyeliğe geri kabul için de BM Şartı́nın 4. maddesine ilişkin prosedürün uygulanması gerekmektedir, zira anılan durumlarda üyeliğin sona ermesiyle yeni bir durum ortaya çıkmaktadır. Mamafih, uygulamada gerek Genel Kurul gerekse Güvenlik Konseyi'nden itiraz söz konusu olmayınca, 4. maddeye ilişkin prosedürün tam olarak izlenmediği görülmektedir. Somut örnek olarak, Endonezya ${ }^{7}$ ile Suriye vakaları bulunmaktadır. Suriye, 1958 yılında Mısır ile birleşmesiyle hem uluslararası hukuk süjesi olma statüsünü hem de BM'deki yerini kaybetmiştir. ${ }^{8}$ Mısır'dan 1961 yılında ayrıldıktan sonra, bağımsız bir devlet olarak, BM üyeliğinin geri verilmesini talep etmiştir. Suriye'nin üyeliğe geri kabulüne ilişkin ne Güvenlik Konseyi ne de Genel Kurul tarafından resmi bir karar alınmamıştır. Genel Kurul Başkanı, Suriye'nin üyeliğe geri kabulüne ilişkin herhangi bir itiraz olup olmadığını sormuş ve üye devletlerden itiraz gelmemesi üzerine, Suriye'yi BM'deki yerlerini almaya davet etmiştir. Nihayetinde, Suriye'nin üyeliğe geri kabulünde kolaylaştırılmış bir prosedür benimsenmiştir. ${ }^{9}$

4 İlk olarak, 1946 yılından itibaren BM Genel Sekreteri tarafindan tarafsız kalmak için BM'ye üye olmayan İsviçre için tasarlanan gözlemci üye statüsü daha sonra BM’ye üye olan Avusturya, Finlandiya, İtalya ve Japonya için de öngörülmüştür.

5 Erdem Denk, Uluslararası Örgütler Hukuku: Birleşmiş Milletler Sistemi, Siyasal Kitapevi, Ankara, 2015, s.156; Tayyar Arı, Geçmişten Günümüze Orta Doğu: Savaş, Siyaset, Diplomasi, Bursa Yay., Bursa, 2014.

6 Benedetto Conforti, The Law and Practice of the United Nations, Martinus Nijhoff Publishers, The Netherlands, 2005, s.38.

7 Endonezya (1965) vakası direk olarak üyelikten çekilmeye ilişkin bir örnek olmasına binaen aşağıda detaylı bir şekilde ele alınacaktır.

8 Suriye ve Mısır, 1945'ten beri BM'nin üyeleriydi. Suriye ve Mısır'da 21 Şubat 1958 yılında yapılan halk oylamasıyla iki devlet birleşmiş ve Birleşik Arap Cumhuriyeti kurulmuştur. BM’de de bu iki devlet birleşip tek bir üye olarak BM üyeliğine devam etmiştir.

9 Memorandum Prepared by the Secretariat, "The Succession of States in Relation to Membership in the United Nations”, Yearbook of the International Law Commission, Cilt II, Document A/CN.4/149 and Add.1, 1962, s.104-105. 
Netice itibariyle, üyelikten çekilme konusunun yanında, BM üyeliğine ilişkin diğer hususlardan bahsedilmesiyle, uygulamada BM Şartı'nda düzenlenmiş veya düzenlenmemiş olan üyeliğe dair mevzuların nasıl çözüme kavuşturulduğunun sunulması amaçlanmıştır. Bu bağlamda, bir devletin üyeliğe girişi için başvurusu veto edilebilmekte, yine aynı sebeple üyeliğin askıya alınması veya üyelikten çıkarılma konuları BM Şartı’nda açıkça düzenlenmesine rağmen bu hükümlere başvurulamaması söz konusu olabilmektedir. Ancak, mevzuatta belirtilmiş olan usule göre hareket edildiği için politik olarak fikir ayrıllı̆ına yol açsa da hukuksal olarak genelde iltibasa veya ciddi bir ihtilafa yol açmamaktadır.

Bunun yanında, gözlemci üyelik statüsü ise BM Şartı́nda düzenlenmemiş olmasına rağmen, ilk olarak BM’ye üye olmayan devletleri örgüte yakın tutmak amacıyla uygulanmış ve hala farklı amaçlarla da başvurulan bir yöntem olarak devam etmektedir. Gözlemci üyelik statüsü, BM’nin kurulduğu yılı takip eden yıldan itibaren uygulanmaya başladığı ve bu konuda yeterli tecrübe elde edildiği için yine iltibasın veya ciddi bir ihtilafın genel olarak söz konusu olmadığı müşahede edilmektedir. Diğer bir önemli nokta ise, üyeliğe dair konuların çözümünde Genel Kurul'un ve Genel Sekreterlik'in etkin rol oynamasıdır.

Kısaca, üyeliğe ilişkin konulardan üyeliğe giriş, üyelikten çıkarılma veya üyeliğin askıya alınması, gözlemci üyelik statüsü ve üyeliğe geri kabul gibi hususların genel olarak belli bir zemine oturtulduğu ve ciddi bir soruna gebe olmadığı görülmektedir. Mamafih, BM’nin en acemi olduğu ve hem politik hem de hukuki uyuşmazlığa zemin oluşturma potansiyeli yüksek olan konu üyelikten çekilme' mevzusudur. Zira BM Şartı’nda sarih bir düzenleme bulunmadığı gibi soruna ilişkin yol gösterebilecek düzeyde bir tecrübe birikimi de söz konusu değildir. Bu noktada, BM üyeliğine ilişkin mezkûr konulardaki tecrübeler, üyelikten çekilmeye dair mevzuat eksikliğinin sebep olabileceği problemlere çözüm geliştirmede ipuçları sunabilmeleri açısından önem arz etmektedir diyebiliriz.

\section{Üyelikten Çekilme}

BM Şartı́nın bir üyenin kendi rızası ile üyelikten çekilip çekilemeyeceği konusunda sessiz kalması, gelecekte bir üye devletin üyelikten çekilme talebi söz konusu olduğunda 'nasıl bir prosedür izlenebilir?' sorusunu cevapsız bırakmaktadır. Buna binaen, bu suale cevap verebilmek adına, BM Şartı ile beraber bazı kaynakların incelenmesi lazım gelmektedir. Bu çerçevede, incelenmesi gereken üç temel enstrümandan bahsetmek mümkündür. Bunlar:

i. BM San Francisco Konferansı Komisyonu'nun Raporu (travaux préparatoires) (1945),

ii. 1965 Endonezya örneği,

iii. Viyana Andlaşmalar Hukuku Sözleşmesi, 1969.

Bazı hukukçular, BM üyeliğinden çekilme hususunu sadece Komisyon raporu ve BM Şartı́na göre ele almıştır; bazıları ise bunlara ek olarak, MC Misakı ve diğer uluslararası kuruluşların kuruluş andlaşmaları ile mukayese yoluna da gitmiştir. Başvurulan bu yöntemlerdeki farklılığın en önemli nedeni, konuyu ele alış tarihleri diyebiliriz. Mesela, Kelsen'in 1948 yılında "Withdrawal from the United Nations” başlıklı çalışmasını kaleme aldığında henüz Endonezya örneği yaşanmadı̆̆ı gibi, rebus sic stantibus ilkesi (koşullarda köklü değişiklik) de henüz VAHS'da kodifiye edilmemişti. Mevcut çalışma ise, konuyu mezkûr üç temel enstrüman ile sınırlandırmakla beraber, BM üyeliğinden çekilmeye dair güncel gelişmeler ile diğer uluslararası kuruluşlara ait örneklere de değinmektedir. 


\section{BM San Francisco Konferansı Komisyonu'nun Raporu: Travaux Préparatoires (1945)}

Bir andlaşma öncesi yapılan müzakerelerin resmi kayıtları olan travaux préparatoires (hazırlık çalışmaları), bir andlaşmanın yorumlanması aşamasında niyetini belirlemeye yönelik başvurulan yararlı bir araçtır. 1969 VAHS'de hazırlık çalışmaları'nın bir andlaşmanın yorumlanması aşamasında ferî kaynak olarak başvurulabileceği kodifiye edilmiştir. ${ }^{10}$ Bu bağlamda, mevcut çalışma da, üyelikten çekilmeye ilişkin olarak, hazırlık çalışması olan San Fransisco Konferansı sırasında düzenlenmiş bir Komisyon raporunu ${ }^{11}$ inceleyecektir.

Birleşmiş Milletler San Francisco Konferansı Komisyonu'nun bir alt komisyonunun görüşüne göre, üyelikten çekilmeye dair hükümler Dumbarton Oaks Konferansı'nda düzenlenen tasarılara kasti olarak dâhil edilmemişti. ${ }^{12}$ Bunun temel nedeni olarak, daimi yani kalıcı bir örgüt kurulmasının amaçlanması gösterilmektedir. Bununla beraber, BM'nin MC'nin zayıf durumuna düşmemek için böyle bir önlem aldığı kabul edilmektedir. ${ }^{13}$ Bir bakıma, böyle bir hükmün kasti suretle dâhil edilmemesi, üyelerin, üyelikten doğan vecibelerden kaçınmak veya BM üyeliğini devam ettirmenin kendi çıarlarına ters düşeceği gibi saiklerle üyelikten tek taraflı çekilmelerini önleme niyeti taşımaktaydı. Filhakika, Japonya, Almanya ve Paraguay gibi ülkeler MC üyeliğinden ulusal çıkarları ile Cemiyet'in çıkarları çatıştığı için çekilmişlerdir. Ayrıca, MC Misakı, sarih bir şekilde, üyelikten çekilmeyi iki yıl öncesinden bildirme şartına bağlamış ${ }^{14}$ olmasına karşın, anılan devletler bir ön bildirimde bulunmaksızın üyelikten çekilmişlerdir.

BM Şartı’nın son halinin verildiği San Francisco Konferansı'nda, üyelikten çekilmeye dair açık bir hükmün Şart'a eklenip eklenmeyeceği sorusu komisyonda tartışılmıştır. ABD, her BM üyesi devletin üyelikten çekilme hakkına sahip olduğunu belirtmiştir. Sovyetler Birliği de benzer şekilde, üyelikten çekilmenin egemenliğin ifadesi olduğu yönünde görüş bildirmiştir. ${ }^{15}$ İngiltere ise, BM Şartı’nda MC Misakı'nın aksine bir üyenin üyelikten çekilme hakkının olmaması gerektiğini savunmuş ve bunun örgütün hızla değişen dünyanın şartlarına intibakını sağlamak açısından önemli olduğunu vurgulamıştır. Ancak, İngiltere, $A B D$ ve Sovyet temsilcilerinin üyelikten çekilme konusuna ilişkin tutarsız açıklamalar yaptıklarını da belirtmek gerekmektedir. ${ }^{16}$ BM Şartı'na şekil veren başat aktörler olan ABD, İngiltere ve Sovyetler Birliği, eğer gerçekten de üyelikten çekilme hakkının olmasını veya olmaması gerektiğini savunuyorlarsa, neden böyle bir düzenlemeyi Şart'a ekleme hususunda isteksiz davranmışlardır? Acaba, üyelikten çekilme hakkını kendileri dışındaki diğer devletlerin kullanmaması için mi üyelikten çekilme hususunda sair bir düzenleme koymaktan imtina ettiler?

10 VAHS, 1969 32. madde: "çok açık bir şekilde saçma olan veya makul olmayan bir sonuca götürüyorsa, manayı tespit etmek için andlaşmanın hazırlık çalışmalarına ve yapılma şartları dâhil, tamamlayıcı yorum araçlarına başvurulabilir."

11 Birleşmiş Milletler San Francisco Konferansı (UNCIO), 1945, Doc.314.

12 Hans Kelsen, "Withdrawal from the United Nations", The Western Political Quarterly, Cilt 1, No.1, 1948, s.29.

13 Ibid.

14 MC Misakı 1. maddesinin üçüncü bendi uyarınca; “Cemiyet' in her üyesi, iki yıl önceden haber vermek ve ayrıldığı anda, bu Misak’ın yüklediklerini de içermek üzere, uluslararası bütün yükümlülüklerini yerine getirmiş bulunmak koşuluyla, Cemiyet'ten çekilebilir." Misak üyelikten çekilmeyi sadece iki yıllık ön bildirim şartına değil, aynı zamanda bu süre zarfında tüm sorumlulukları yerine getirme koşuluna da bağlamıştır.

15 Birleşmiş Milletler San Francisco Konferansı (UNCIO), 1945, Doc.215.

16 Egon Schwelb, "Withdrawal from the United Nations: The Indonesian Intermezzo", The American Journal of International Law, Cilt 61 No.3, 1967, s.662. 
Nihayetinde, üyelikten çekilme konusunun BM Şartı'na eklenmesi oylamaya sunulmuş ve yapılan oylama sonucu 19 olumlu 22 olumsuz oy kullanılmıştır. ${ }^{17}$ Nitekim her ne kadar komisyon konu ile ilgili herhangi bir hükmün BM Şartı'na konulmaması fikrini benimsemiş olsa da, bu kararın bazı istisnai noktalarla birlikte rapora konulmasını da 38 oyla kabul etmiştir. Komisyon Raporu:

Komisyon BM Şartı́na bir üyenin BM üyeliğinden çekilip çekilemeyeceğine dair açık bir düzenleme konmaması görüşünü benimsemiştir. Komisyona göre, üye olacak olan ulusların en önemli görevi uluslararası barış ve güvenliğin korunması için Örgüt ile iş birliğini sürdürmeleridir. Ancak, bir üye beklenmeyen şartlardan dolayı üyelikten çekilmek ve uluslararası barış ve güvenliği sağlama yükünü diğer üyeler üzerinde bırakmak zorunda olduğunu hissederse, ilgili üyeyi Örgüt ile iş birliğine zorlamak Örgüt'ün amaçlarından biri değildir. Eğer Örgüt'ün barışı sağlayamadığına dair kanaat oluşmuşsa veya bunu sadece hukuka ve adalete zarar vererek yapabiliyorsa, üyelikten çekilmeler veya Örgüt'ün bazı dağılma şekillerinin ortaya çekilmesinin kaçınılmaz olduğu açıktır. Eğer bir üyenin hakları ve sorumlulukları razı olmadığı ve kabul edemeyeceği Şart değişikliği ile değiştirilirse, ya da eğer bir değiş̧iklik Genel Kurul'da veya genel bir konferansta usulüne uygun gerekli çoğunlukla kabul edilir ama değişiklik yürürlüğe konmazsa yine ilgili üye, Örgüt'te kalmaya zorlanamaz. Bu mülahazalardan dolayı Komisyon Şart'a hassaten üyelikten çekilmeye izin veren veya üyelikten çekilmeyi yasaklayan resmi bir hüküm koymaya dair tavsiyede bulunmaktan imtina etme kararı vermiştir. ${ }^{18}$

Raporu incelemek, hem BM kurucularının üyelikten çekilme düzenlemesine dair niyetlerini anlama hem de sunmuş oldukları istisnaların uygulanabilir bir prosedür sunup sunmadığı açılarından önem arz etmektedir. Lakin rapor herhangi bir şekilde ne BM Şartı'na ne de ek metinlere eklenmiştir. $\mathrm{Bu}$ yüzden, Kelsen gibi bazı yazarlar raporun hukuki bir bağlayıcılığının bulunmadığını iddia ederken, Schwarzenberger ${ }^{19}$ gibi bazı yazarlara göre de rapora, andlaşmayı yorumlama amacıyla başvurulabilir. ${ }^{20}$ Mevcut çalışma da Kelsen'in aksine, raporu andlaşmayı yorumlama açısından başvurulabilecek bir kaynak olarak değerlendirmektedir. Bununla beraber, raporun istisnai durumlar olarak belirlediği hususların BM Şartı ile çelişkiler içermesi ve bazı önemli sualleri cevapsız bırakması nedeniyle Kelsen ile aynı fikri paylaşmaktadır.

İlk olarak, Komisyon 'beklenmeyen şartlar' ortaya çıkması durumunda ifadesini kullanıyor, ancak, kimin 'beklenmeyen durumların' ortaya çıkıp çıkmadığını belirleyeceği sorusunu cevapsız bırakmıştır. Bununla beraber, kim tarafından ve nasıl 'Örgüt'ün barışı sağlamadığına' dair değerlendirme yapılacağı konusu belirsizdir; çünkü BM Şartı bu konuda herhangi bir asli organı görevlendirmemiştir. ${ }^{21}$ Bu yüzden, burada üye bir devletin çekilme sebeplerini kendi kendine tayin etmesinin söz konusu olacağı düşünülebilir. Ancak, genel olarak üyeliğin diğer işleyişlerine ilişkin uygulamalara bakıldığında Genel Sekreterlik' in bu konuda ilk aşamada görevli olarak muhatap alındığı ve nihai karar için ise Güvenlik Konseyi’nin yetkili olduğu görülmektedir.

17 Birleşmiş Milletler San Francisco Konferansı, Doc.314.

18 Ibid.

19 A. C. Cilliers, "Withdrawal from the United Nations and the Question of Credentials", South African Yearbook of International Law, Cilt 1, 1975, s.6.

20 Schwelb, "Withdrawal from the United Nations", s.661.

21 Kelsen, "Withdrawal from the United Nations", s.34-35. 
İkinci olarak, "Eğer bir üyenin hakları ve sorumlulukları, razı olmadığı ve kabul edemeyeceği bir sözleşme değişikliği ile değiştirilirse üye, Örgütte kalmaya zorlanamaz." ifadesi aslında BM Şartı́nın 108. ile 109. maddeleri ile çelişmektedir. ${ }^{22}$ Zira BM’nin tüm üyeleri kabul etmiş oldukları BM Şartı'nın 108. maddesi uyarınca ${ }^{23}$ Şart'ta yapılacak herhangi bir değişiklik söz konusu olduğunda, bu değiş̧iklik 2/3 çoğunluk (Güvenlik Konseyi daimi üyeleri dâhil) tarafından kabul edildikten sonra, tüm BM üyeleri için bağlayıcılık kazanır. Diğer bir deyişle, Şart'ta yapılan bu değişiklik sadece olumlu oy kullanan üyeler için geçerli veya olumsuz oy kullanan üyeler için geçersizdir şeklinde bir ayrıma gitmemiştir. Zaten, özellikle 108. maddenin amacı, MC Misakı'nın 26. maddesinde benimsenen "yapılan değişikliğin, olumsuz oy kullananları bağlamadığı ve olumsuz oy kullananların bu sebeple MC üyeliğinden ayrılabileceği” kaidesi ile sağlanan üyelikten çekilme hakkının BM üyesi devletlere tanınmamasıdır. Bu noktada, İngiltere'nin Komisyon'da 108. madde ile ilgili yapmış olduğu açıklamada da aynı şeye vurgu yapılmaktadır: "yapılan değişiklikler olumsuz oy kullanan üyeler de dâhil tüm üyeler için bağlayıcılık kazanır. Hiçbir üye yapılan değişikliği sebep göstererek üyelikten çekilemez." ${ }^{24}$ Ayrıca, yine BM Şartı́nın 108. ve 109. maddelerine göre, değişiklik yapıldıktan sonra 'mevcut kurallar' ile 'değişiklik sonucu oluşan kurallar' arasında bağlayıcılıkları yönünden bir fark yoktur. ${ }^{25}$ Netice itibariyle, Örgüte üye olurken onaylamadığı değişiklikleri de kabul ettiğini taahhüt etmiş bir BM üyesi, komisyon raporunun belirttiği haliyle üyelikten çekilme sebebi olarak yapılan bir değişikliği ileri sürmesi durumunda Şart'ın mezkûr maddeleri ile uyuşmazlık söz konusu olacaktır.

Üçüncü olarak, Komisyon, üye devletin desteklediği 'bir değişikliğin usulünce kabul edilip yürürlüğe konmaması' durumunda söz konusu devletin üyelikten çekilmeyi talep edebileceğini belirtmiştir. Kelsen, Komisyon'un bu yorumunu anlamanın gerçekten de güç olduğunu ifade etmiştir. Ona göre, bu durumda bir üye devletin bunu bahane edip çekilmek istemesi yine yerinde olmaz çünkü bu değişiklik yürürlüğe girmediğinde mevcut durum korunmuş olacak yani hâlihazırda zaten kabul edilmiş olan durum devam etmiş olacaktır. Bununla beraber, bir üye devlet bir değişikliğin olmasını belli sebeplerden dolayı çok arzu eder ve bu değişiklik $2 / 3$ çoğunlukla kabul edilmesine rağmen yürürlüğe konulmazsa üyelikten çekilmeyi de isteyebilir. Ancak, Komisyon, böyle bir sınırlandırma getirmemiştir. Yani herhangi bir değişiklik şeklinde genel bir terim kullanılmış ve herhangi bir üye devletin bu durumu üyelikten çekilme sebebi olarak kullanmasına müsaade edecek şekilde yorumlanmasının önünü açmıştır. Filhakika, belli ölçüler konulmaması, durumun tanımlanmasını güçleştirmiştir. ${ }^{26} \mathrm{Bu}$ bağlamda, ne kadar süre sonra değişikliğin yürürlüğe girmemiş olarak değerlendirileceği belirtilmemiş, diğer bir ifadeyle, yürürlüğe girip girmediğini ölçme kıstasları belirsiz bırakılmıştır.

Bununla birlikte, bir üyenin üyelikten çekilme talebinin nedenini mevcut Şart'ta ya da yapılan değişiklikle kendisinden beklenen yükümlülükleri yerine getirmemek ve bunlardan kurtulmak amacına dayandırması, yine Şart'in temel prensipleri ile çelişebilir. ${ }^{27}$ Zira böyle bir amaçla üyelikten çekilmek, üyelikten çekilen devleti yükümlülükten kurtaramayabilir, çünkü Şart'ın 2. maddesinin

22 Ibid.

23 “İşbu Andlaşma’da yapılacak değişiklikler, Genel Kurul üyelerinin üçte iki çoğunluğu tarafından kabul edilip, Güvenlik Konseyi’nin sürekli üyelerinin tümünü kapsamak üzere Birleşmiş Milletler üyelerinin üçte ikisi tarafından her birinin anayasa kuralları gereğince onaylandığı zaman, tüm Birleşmiş Milletler üyeleri için yürürlüğe girer."

24 Schwelb, "Withdrawal from the United Nations", s.662.

25 Kelsen, "Withdrawal from the United Nations", s.35.

26 Ibid.

27 Ibid. 
altıncı fikrası uyarınca, üye olmayan devletlerin de uluslararası barış ve güvenlik söz konusu olduğunda, Şart'in ilkelerine uyması gerekmektedir. ${ }^{28}$ Ancak, bunun Örgüt üyeliğinden doğan tüm yükümlülükleri kapsamadığını da belirtmek gerekir. Mesela, Örgüt üyeliğinin getirmiş olduğu bir takım mali yükümlülükler üye olmayan devleti kapsamayacaktır. Netice itibariyle, üyelikten çekilmek her ne kadar üyelikten kaynaklı genel yükümlülüklerden muafiyet anlamına gelse de, uluslararası barış ve güvenliği ilgilendiren hususlarda ilgili devletin yükümlülükten kesin olarak muafiyeti mümkün olmayabilir. Bu bağlamda, Komisyon’un uluslararası barış ve güvenliği ilgilendiren yükümlülükleri hariç tutması gerekirdi diyebiliriz.

Son olarak, yine yukarıda anılan Şart'taki barış ve güvenliğin korunması gerekçesi ile Güvenlik Konseyi’ne tanınan geniş yetki ile Komisyon'un ifade ettiği Örgüt'ün 'bir devleti üye olmaya zorlama gibi bir amacı yoktur.' ifadesi arasında bir çelişki söz konusu olabilir. Filhakika, uygulamada herhangi bir örneği mevcut olmasa da, BM Şartı 39. maddenin verdiği yetki ile Güvenlik Konseyi 'bir üye devletin üyelikten çekilmesini’ barış ve güvenliğe tehdit olarak yorumlayıp, üyelikte kalmaya zorlaması söz konusu olabilir. ${ }^{29}$

Nihai olarak, inceleme neticesinde iki sonuca ulaşılmıştır. Birincisi, üyelikten çekilmeye dair mevzuat bilinçli olarak BM kurucuları tarafindan Şart’a eklenmemiştir. Bu husus, aşağıda BM üyeliğinden çekilme mevzusunu 1969 VAHS açısından değerlendirme aşamasında yol gösterici olacaktır. İkinci olarak, Komisyon'un sunduğu rapor BM Şartı́nın yorumlanması açısından önemli bir kaynak olsa da, raporda belirtilmiş olan 'üyelikten çekilmeye zemin olarak belirtilen şartlar' BM Şartı ile içerdiği çelişkilerden ötürü soruna yönelik çözüm geliştirmede yol gösterici veya açıklayıcı özellikleri haiz değildir.

\section{Endonezya Örneği (1965)}

Endonezya; Güneydoğu Asya'daki İngiliz kolonileri olan Malaya, Singapur, Saravak ve Sabah bölgelerinin birleşmesiyle oluşan Malezya devletini tanımamakta diretiyor ve karşı çıkıyordu. Daha sonra, Malezya’nın Güvenlik Konseyi geçici üyeliğine getirilmesi durumu söz konusu olunca, Endonezya böyle bir gelişme durumunda BM üyeliğinden çekileceğini dile getirmiştir. Malezya Güvenlik Konseyi geçici üyeliğine seçilince, Endonezya, 20 Ocak 1965'de üyelikten çekildiğini bildiren bir mektubu BM Genel Sekreterliği’ne yollamış, Genel Sekreter de durumu hem Güvenlik Konseyi'ne hem de BM Genel Kurulu'na ve diğer üye devletlere bildirmiştir.

BM, kuruluşundan itibaren ilk defa böyle bir tecrübe yaşıyordu ve hala da BM literatüründe, Endonezya örneği gibi gerçek bir üyelikten çekilme vakası bulunmamaktadır. Endonezya hükümeti de, Genel Sekreter'e yollamış olduğu mektupta, almış oldukları kararın, daha önce örneği olmayan olağandışı bir adım olduğunu itiraf ediyordu. ${ }^{30}$

Diğer taraftan, Endonezya'nın üyelikten çekildiğini ilan etmesine mukabil, BM'den üyelikten çekilme hareketini onaylayan ya da reddeden resmi bir tepki gelmemiştir. BM tarafından ilgili devletin üyelikten çekilme eyleminin kabul edildiğine ilişkin tek kanıt, o dönemde BM tarafından yayınlanan

28 BM Şartı 2(6): "Örgüt, Birleşmiş Milletler üyesi olmayan devletlerin de, uluslararası barış ve güvenliğin korunmasının gerektirdiği ölçüde bu ilkelere uygun biçimde hareket etmesini sağlar.”

29 Kelsen, "Withdrawal from the United Nations", s.40.

30 Dr. Subandrio, "Letter of Indonesia on Withdrawal from United Nations”, United Nations Document A/5857, 20 Ocak 1965. 
resmi üye listesinde Endonezya'ya yer verilmemiş olmasıdır. ${ }^{31}$ Diğer taraftan, BM üyeliğine ilişkin diğer konularda yetkili olan ne Güvenlik Konseyi ne de Genel Kurul konuyu gündeme almış ve konuya ilişkin herhangi bir cevap vermiştir. Sadece, Genel Sekreter üzüntülerini ifade edip sorunun bir an önce çözülmesi temennisinde bulunan bir mukabelede bulunmuştur.

BM Şartı́nın, üye devletlerin üyelikten çekilme hakkına ilişkin bir düzenlemesi olmamasına rağmen, Endonezya’nın böyle bir karar alması, bu olayın hukuki ve uygulanabilirlik cihetlerine ilişkin soruları da beraberinde getirmiştir. Bir devletin BM üyeliğinden çekilme hakkı var mı, eğer böyle bir hakkı yoksa üyelikten çekilme gibi görünen bu eylemin sonuçları nelerdir? ${ }^{32}$ Bu bağlamda, Endonezya'nın üyelikten çekilme ilanından tekrar üyeliğe geri kabulüne kadar geçen süreci değerlendirmemiz gerekmektedir.

İlk olarak, yukarıda değinildiği gibi ne Güvenlik Konseyi ne de Genel Kurul tarafından konuya ilişkin herhangi bir resmi işlem gerçekleştirilmemiştir. BM'nin üyeliğe ilişkin konularda yetkili olan en önemli iki asli organının sessiz kalması, üyelikten çekilmeye dair güçlü bir sonuca varmayı zorlaştırmıştır. Zira BM tarafından konuya ilişkin açık resmibir sürecin işletilmemesi, meselenin daha sonra yaşanabilecek üyelikten çekilme vakalarında rol model olma özelliği kazanmasına mani olmuştur.

Diğer taraftan, Genel Sekreter'in verdiği cevap ise yine Endonezya tarafından verilen kararın geçerliliğini saptamak açısından müphem kalmıştır. Verilen cevapta, Genel Sekreter, öncelikle BM Şartı́nın böyle bir düzenleme içermediğini belirtmiş ve yukarda anılan Komisyon raporuna da atıf yapmıştır. Daha sonra, konuyu Güvenlik Konseyi’ne ve Genel Kurul'a ilettiğini ve BM üyeleriyle de danışma halinde olduğunu belirttikten sonra en kısa zamanda Endonezya'nın BM ile tekrar tam işbirliğine geri dönmesini umut ettiğini ifade etmiştir. Genel olarak, Genel Sekreter’in verdiği cevabı incelediğimizde, Endonezya’nın üyelikten çekilme kararının geçerliliğini ima eden bir dil kullanmaktan imtina ettiği görülmektedir. ${ }^{33}$

Son olarak, Endonezya’nın üyelikten çekilme ilanına İtalya ve İngiltere gibi bazı devletlerden de tepkiler gelmiştir. İngiltere, konuya ilişkin yaptığı açıklamada; Endonezya’nın üyelikten çekilme gerekçesi olarak ileri sürmüş olduğu 'Malezya'nın Güvenlik Konseyi üyeliğine getirilmesi ve bunun BM Şartı́nın 23. maddesini ihlal ettiği' iddialarının, üyelikten çekilmeye meşru zemin oluşturmaktan uzak olduğunu belirtmiştir. Zira İngiltere'ye göre bu gerekçelerin hiçbiri istisnai durumlardan değildir. ${ }^{34}$ İtalya ise, öncelikle BM Şartı'nın üyelikten çekilmeye dair bir düzenlemesinin bulunmadığına dikkat çekmekle beraber, yukarıda anılan Komisyon raporunun konuya ilişkin tek çalışma olduğunu ancak üyelikten çekilmeye dair sarih bir prosedür sunmadığını belirtmiştir. ${ }^{35}$ Bununla beraber, böyle önemli bir konunun Şart'ta düzenlenmemiş olmasının kaygı verici olduğunu ekleyerek, en kısa zamanda bu eksikliğin giderilmesi temennisinde bulunmuştur. ${ }^{36}$ İngiltere ile İtalya'nın tepkilerinde buluştukları ortak nokta ise, üyelikten çekilerek BM’nin temel prensiplerinden kaçınılamayacağıydı.

31 Denk, Uluslararası Örgütler Hukuku, s.158.

32 Frances Livingstone, "Withdrawal from the United Nations: Indonesia", The International and Comparative Law Quarterly, Cilt 14 No.2, 1965, s.638.

33 Schwelb, "Withdrawal from the United Nations:", s.666.

34 "Letter Dated 8 March 1965 From the Deputy Permanent Representative of the United Kingdom of Great Britain and Northern Ireland to the United Nations Addressed to the Secretary-General”, UN Doc No. s/6229, 12 Mart 1965, s.2.

35 "Note Verbale Dated 13 May 1965 from the Permanent Representative of Italy to the United Nations Addressed to the Secretary-General”, UN Doc No. s/6356, 17 Mayıs 1965.

36 Ibid., s.3-4. 
Nitekim gerek Genel Sekreter'in gerekse diğer iki devletin cevaplarına bakıldığında, Endonezya’nın üyelikten çekilmesinin meşru olmadığı yönünde bir eğilimleri oldukları görülmüştür. Lakin bu tepkiler arasında güçlü bir bağ veya ortak cihet söz konusu olmadığı gibi, BM'nin konuya ilişkin resmi bakış açısını temsil etmekten de uzaktır. Bu da şüphesiz konuya ilişkin sarih bir düzenlemenin olmamasından kaynaklanmaktadır. Ayrıca, Komisyon raporuna referans edildiği görülse de, yukarıda da değinildiği gibi, Komisyon raporu üyelikten çekilmeye dair tenvir edici bir prosedür sunmaktan uzaktır ve tanımlamış olduğu üyelikten çekilmeyi haklı kılabilecek istisnalar da BM Şartı ile bağdaşmamaktadır.

Son olarak, Endonezya, üyelikten çekilme kararının üzerinden yaklaşık iki yıllık bir süre geçmesinden sonra 19 Eylül 1967 tarihinde yeniden üyeliğe geri dönmek istediğini belirtmiştir. $\mathrm{Bu}$ talebi Genel Sekreterce olumlu karşılanmış ve yukarıda anılan Suriye örneğindekine benzer bir prosedür izlenmiştir. Nihayetinde geri kabule ilişkin herhangi bir itiraz söz konu olmayınca, Endonezya'nın BM'deki yerini almasına müsaade edilmiştir. Lakin bu ülkeden üyelikten çekildiğini iddia ettiği yaklaşık iki yıl süre zarfında üyelikten kaynaklanan bazı borçların ödenmesi de istenmiştir. Diğer bir ifadeyle, Endonezya’nın sanki üyelikten hiç ayrılmamış gibi üyelik yükümlülüğünden kaynaklanan birikmiş bazı borçlarını ödemesi talep edilmiştir. Endonezya hükümeti birikmiş borçların faizinin düşürülüp, taksitlendirilmesi kaydıyla bu talebi kabul etmiştir. ${ }^{37}$

Ortaya çıkan tabloya baktığımızda, Endonezya, sanki üyeliğini dondurmuş gibi, herhangi bir itiraza maruz kalmadan üyeliğine devam etmiştir. Endonezya’nın üyeliğe geri kabulü aşamasında, aktif olarak üyelikte bulunmadığı veya daha doğrusu üyelikten çıktığını iddia ettiği süre boyunca oluşan borçların da tahsil edilmesi, aslında Endonezyánın tek taraflı üyelikten çekilme kararının üyeliği sona erdirme etkisi doğurmadığını göstermektedir. Bu örnekten hareketle, üyelikten çekilme düzenlemesi olmasa da uygulamada pek bir kriz yaşanmadan da sorun çözülebiliyor şeklinde bir sonuç çıarılabilir. Ancak, Endonezya’nın üyelikten çekildiğini iddia etmesi 2 yıl dahi sürmemiştir. Peki, bu süre daha uzun olsaydı ve geri kabul aşamasında daha büyük bir borç ile karşılaşsaydı nasıl bir süreç yaşanırdı? Ayrıca, Endonezya üyelikten çekilmeyi bir diplomatik baskı veya tepki aracı olarak kullanmış olabilir. ${ }^{38}$ Peki ya gerçekten üyelikten tamamen ayrılmak isteseydi daha karmaşık bir süreç ortaya çıabilir miydi? Böyle bir senaryoda muhtemelen gerek Genel Kurul gerekse Güvenlik Konseyi durumu onaylamayacak ve daha ciddi tepkiler verecekti.

Sonuç olarak, BM kanadından Endonezya'nın üyelikten çekilme kararına ilişkin sarih bir resmi açıklama yapılmamıştır. Bununla beraber, üyeliğe geri dönme kararına ilişkin de Şart'ta düzenlenmiş olan üyeliğe kabul prosedürü yerine basitleştirilmiş bir süreç izlenmiştir. Zira üyeliğe geri kabul aşamasında üyelikten çekilmiş bir devlet gibi muamele görmemiştir. Eğer üyelikten gerçekten çekilmiş olsaydı, yeniden üyeliğe başvurması gerekecekti ki bu da Şart'ın 4. maddesinin uygulanması demekti. Bir nevi tek taraflı etki doğurmayan üyelikten çekilme iddiası söz konusu olmuştur. Anılan bu sebeplerle, Endonezya tecrübesinin, BM Şartı́nın üyelikten çekilmeye dair eksikliğini gidermede yol gösterici olamayacağını söylemek mümkündür.

37 Schwelb, "Withdrawal from the United Nations", s.670.

38 Suudi Arabistan, Güvenlik Konseyi geçici üyeliğine seçilmesine rağmen, protesto amaçlı olarak bu üyeliği reddederek, daha önce örneği görülmemiş bir karara imza atmıştır. Aslında, 1950’de Sovyetler Birliği de Güvenlik Konseyi’nde oturmayı reddetmişti, lakin üyeliğini reddetmemişti: Robert. F. Worth, "Saudi Arabia Rejects U.N. Security Council Seat in Protest Move”, The New York Times, 18 Ekim 2013 https:/ www.nytimes.com/2013/10/19/world/middleeast/ saudi-arabia-rejects-security-council-seat.html (Erişim Tarihi 16 Haziran 2014). Ayrıca, devletlerin üyelikten çekilmeyi bir baskı aracı olarak kullandıklarına dair bkz. Helfer, “Terminating Treaties”, s.646. 


\section{Viyana Andlaşmalar Hukuku Sözleşmesi (1969)}

1969 VAHS, bir sözleşmede üyelikten çekilmeye dair düzenleme bulunmadığında izlenebilecek yolları ele almıştır. Bu bağlamda ilk olarak, VAHS 56. madde ${ }^{39}$ "Sona erme, fesih veya çekilme hususunda hiçbir hüküm ihtiva etmeyen bir andlaşmanın feshi veya andlaşmadan çekilme" konusunu düzenlemiştir. $\mathrm{Bu}$ maddenin birinci fikrası, üyelikten çekilmeye dair bir düzenleme olmayan andlaşmalardan çekilebilmek için aşağıdaki şartları belirler:

1. Sona ermesiyle ilgili hiçbir hüküm taşımayan ve fesih veya çekilmeyi öngörmeyen bir andlaşma, feshe veya çekilmeye tabi değildir, meğerki:

a- tarafların fesih veya çekilme ihtimalini kabul etme niyetleri tespit edilsin veya;

b- fesih veya çekilme hakkı andlaşmanın niteliğinden zımnen çıkarılsın.

$\mathrm{Bu}$ maddeye göre, $\mathrm{BM}$ üyeliğinden çekilmenin mümkün olabilmesi için ya andlaşmanın bütününe bakılarak buna izin verdiği anlamı çıkmalı ya da diğer tüm üyelerin buna rızası olmalıdır.

Birinci fikranın a bendinin BM açısından uygulanabilirliği pek mümkün değildir. Zira mevcut 193 üyenin bir üyelikten çekilme vakası karşısında oy birliği ile hareket etmesi pek uygulanabilir bir durum değildir. Mesela, Kuzey Kore 25 Ağustos 1997 tarihinde Uluslararası Medeni ve Siyasi Haklar Sözleşmesi’nden tek taraflı çekilmeye çalışmıştır. Ancak BM İnsan Hakları Komitesi buna karşılık olarak, Kuzey Kore’nin böyle bir adımı tek taraflı atamayacağını çünkü haklar sözleşmesinin bilinçli olarak 'çekilme' hükmünü düzenlemediğini ve bu yüzden ancak diğer tüm tarafların onayı durumunda çekilebileceğini belirtmiştir. ${ }^{40} \mathrm{Bu}$ yüzden, Kuzey Kore Sözleşmenin tarafı olarak kalmıştır. Zira taraf olan 170 devletin böyle bir hususta oy birliğine varması oldukça güçtür. Benzer şekilde, birinci fıkranın a bendinin, üye sayısı 193 olan BM bakımından uygulanabilirliği de kanaatimizce mümkün görünmemektedir.

Aynı fikranın b bendi açısından kesin bir şey söylemek mümkün değildir. Hatta Kelsen gibi bazı yazarlar, BM Şartı'nın, üyelikten çekilme hakkı içermeyen 1928 Paris Paktı'ndan daha az bir süre için yapıldığını kimse iddia edemez deyip, BM kurucularının kasti olarak Şart’a üyelikten çekilmeye dair herhangi bir düzenleme eklemediğini belirtmiştir. ${ }^{41}$ Diğer bir deyişle, BM Şartı’nın üyelikten çekilmeye müsaade etme niyetinin olmadığını vurgulamıştır. Bununla beraber, BM kurucuları, üyelikten çekilme konusunun aslında San Francisco Konferansı’nda bir Komisyon aracılığı ile görüşülmesini sağlamıştır. Komisyon'dan çıkan sonuç ise üyelikten çekilmeye izin veren ya da yasaklayan bir düzenlemenin Şart’a konmaması, ancak, bunun bazı istisnai durumlarının olabileceğidir. Lakin yukarıda da anıldığı gibi rapora ilişkin somut çekinceler söz konusudur. Bu bağlamda, raporun herhangi bir şekilde Şart’a ve eklerine konmaması, raporun başvurulabilir bir kaynak olup olmadığı hususunda fikir ayrılığına sebep olmuştur. Raporun içerik olarak açıklayıcı ve uygulanabilir bir prosedür sunmaması, raporu daha da etkisiz hale getirmektedir. Sonuç olarak, BM Şartı́nın bütününe bakıldığında üyelikten çekilmeye izin verdiğini söylemek oldukça güçtür.

39 Şunu da not etmek gerekir, VAHS 4. maddesinde ele alınmış olan 'geriye yürümezlik ilkesi gereği', VAHS 56. madde sadece 1969 yılı ve sonrasında BM’ye üye olmuş devletler için geçerlidir ki bu da yaklaşık 66 ülkeye tekabül etmektedir.

40 UN Human Rights Committee (HRC), “CCPR General Comment No. 26: Continuity of Obligations”, CCPR/C/21/ Rev.1/Add.8/Rev.1., 12 Ağustos 1997.

41 Kelsen, "Withdrawal from the United Nations", s.43. 
BM üyeliğinden çekilmeye dair bir düzenleme olmamasından dolayı başvurulabilirliği tartışılabilecek diğer bir araç, koşullarda köklü değişiklik (rebus sic stantibus) ilkesidir. Aslında, bir uluslararası örf-adet hukuku kaidesi olan bu ilke ${ }^{42}, 1969$ VAHS'da kodifiye edilmiştir. Bazı andlaşmaların mahiyeti gereği sınırsı veya uzun süreli olmasına ${ }^{43}$ binaen, anılan ilke andlaşmaya konmasa bile, tarafların bu kaydın konulduğunu prensip olarak kabul ettikleri var sayılmaktadır. ${ }^{44}$

Rebus sic stantibus ilkesi, 1969 VAHS 62. maddesinin birinci fikrası şöyle düzenlenmiştir ${ }^{45}$ :

1. Bir andlaşmanın akdedilmesi sırasında mevcut olan şartlarda meydana gelen taraflarca öngörülmeyen esaslı bir değişikliğe, andlaşmayı sona erdirme veya andlaşmadan çekilme için bir gerekçe olarak başvurulamaz, meğerki;

a- bu şartların mevcudiyeti, tarafların andlaşma ile bağlanma rızalarının esaslı bir temelini teşkil etsin ve;

b- değişiklik andlaşmaya göre hala icra edilecek yükümlülüklerin kapsamını köklü bir şekilde değiştirme etkisini haiz olsun.

Böyle bir durumda, bir taraf andlaşmanın diğer taraflarından andlaşmanın feshedilmesini ister, diğer taraflar da bunu reddeder ve konuyu bir uluslararası mahkemeye götürmezse, ilgili devlet kendisinin artık andlaşmayla bağlı olmadığını ilan edebilir. ${ }^{46} \mathrm{BM}$ için ise, üye devlet Örgüt'ten ayrılmak istediğini beyan eder, eğer bu reddedilirse, konu Örgüt'ün yargı organı olan Uluslararası Adalet Divanı'na (UAD) havale edilir. Ancak, bu konu hakkında kimin kesin hüküm vereceği hususu problemli olmaktadır. Çünkü üye devlet böyle bir iddiayı ileri sürüp ayrılmak istediğinde, BM'de hangi asli organı muhatap alacağı belirsizdir. Daha doğrusu, hangi ana organın üye devletin üyelikten çekilmesine izin verip vermeyeceğine dair bir hüküm yoktur. Ayrıca, UAD sadece devletlerarası davalara bakabildiği için ${ }^{47}$ bu da mümkün olmayacaktır. Çünkü süreç iki devlet arasında değil, bir devlet ile bir Örgüt arasında cereyan edecektir. Bu bağlamda konunun BM bünyesinde ya Güvenlik Konseyi ya da Genel Kurul aracılığıyla UAD’a götürülebilmesi mümkün olacaktır. Lakin bu durumda da UAD'ın vereceği karar ancak tavsiye niteliğinde olacaktır. ${ }^{48}$ Bununla beraber, üye devlet bu durumunu diğer tüm üyelere bildirirse, diğer üye devletlerin de konuyu UAD’a taşıması mümkün olabilir. Çünkü konu artık üye devlet ile Örgüt arasında değil, diğer üye devletler arasındadır. Netice olarak, mevcut durumda, BM üyeliğinden çekilme ancak rebus sic stantibus ilkesi ile mümkün olacaktır.

42 UN General Assembly, "Report of the International Law Commission on the work of its Fifteenth Session UNGA", A/5509, 12 Haziran 1963, s.200.

43 Bazı andlaşmaların tek taraflı üyelikten çekilmeye açık olmadığına dair bkz. G. G. Fitzmaurice, "Second Report on the Law of Treaties. International Law Commission”, A/CN.4/107, 1957; James Crawford, Brownlie's Principles of Public International Law, OUP, Oxford, 2012, s.390.

44 Kamuran Reçber, Uluslararası Hukuk, DORA, Bursa, 2016, s.98.

45 İlgili maddenin ikinci bendine, BM üyeliğinden çekilmeye ilişkin bir özelliği olmamasından dolayı, değinilmemiştir.

46 Nota teatisi andlaşmasıyla 12 mil olarak belirlenen balıkçılık bölgesinin İzlanda tarafından 50 mile çıkarılması üzerine, İzlanda ile Birleşik Krallık arasında oluşan uyuşmazlık UAD’a götürülmüştür. UAD, söz konusu uyuşmazlıkta Birleşik Krallık ile yapılan andlaşmanın şartlarında esaslı bir değişikliğin olmadığını belirterek andlaşmanın geçersizliği iddialarını reddetmiştir. United Kingdom of Great Britain and Northern Ireland v. Iceland (Fisheries Jurisdiction) [1974] ICJ.

47 UAD Statüsü 34(1): "Divan önündeki davalarda yalnız devletler taraf olabilirler."

48 BM Şartı 96(1): "Genel Kurul ya da Güvenlik Konseyi herhangi bir hukuksal sorun konusunda Uluslararası Adalet Divanı'ndan tavsiye görüşü isteyebilir.”. 


\section{Sonuç}

Üyelikten çekilmeye dair bir düzenleme olmamasına karşın, devletlerin kendilerini bu konuda serbest görüp tek taraflı olarak örgütten çekilmeye meyilli oldukları söylenebilir. ${ }^{49} \mathrm{Bu}$ durumda, BM örneğinde bir önlem olarak düşünülen üyelikten çekilme maddesinin düzenlenmemesi, örgütün zayıflığını önlemek yerine daha fazla probleme sebep olabilir. Çünkü üyelikten çekilmeye dair bir düzenleme olmamasına rağmen, bir devletin üyelikten tek taraflı çekilmesi Örgüt'ün itibarını zedelemiş olacaktır. ${ }^{50}$ Mamafih, bir düzenleme olsa bile devletler düzenlemenin şartlarını yerine getirmeden üyelikten çekilebiliyorlar. Milletler Cemiyeti Misakı bu konuda net olarak iki yıllık ön bildirim şartı getirmesine karşın, Japonya, Almanya ve Paraguay gibi bazı ülkeler üyelikten çekilirken böyle bir kurala uyma gereksinimi duymamıştır. Peki, BM Şartı bu konuda sessiz kalıp konuyu müphem mi bırakmalı yoksa sarih bir şekilde düzenlemeye mi gitmelidir?

BM özelinde uygulamalara baktığımızda da, açık bir düzenleme olmadı̆ğ için, üye devletler genellikle üyelikten ayrılma sebeplerini kendileri belirleme yoluna gitmektedirler. ${ }^{51}$ Öne sürdükleri sebeplere baktığımızda, BM üyeliğinden çekilmelerini meşrulaştırabilecek tek yol olan 'koşullarda köklü değişiklik' ilkesi ile bağdaşmadıklarını görmekteyiz. Bu bağlamda, gerek Endonezya’nın başka bir ülkeye olan tepkisini sebep göstermesi, gerekse yakın tarihte ABD'de -bir kongre üyesinin özellikle ekonomik sebepleri ileri sürüp ${ }^{52}$ senatoya BM üyeliğinden çekilmeye dair teklifte bulunması ve son olarak Filipinler Devlet Başkanı’nın, BM kanadından gelen tepkileri, iç işlerine karışılması olarak değerlendirip buna tepki olarak da BM üyeliğinden çekilmekle tehdit etmesi gibi vakaların rebus sic stantibus ilkesine başvurmayı gerektirecek temellerden açık bir şekilde yoksun olduklarını görmekteyiz. ${ }^{53}$

Her ne kadar, MC Misakı'ndaki şartın ihlali, düzenleme getirmenin yetersizliğine delalet etse de, dönemin şartlarını ve her iki örgüt arasındaki yapısal farkları göz ardı etmek de bizi yanılgıya götürecektir. İlk olarak, MC dönemi dünya devletlerinin henüz bir küresel uluslararası örgüt tecrübesi yaşamadığı ve uluslararası hukukun günümüze nazaran devletler üzerinde çok fazla bağlayıcılık oluşturmadığı bir süreçti. ${ }^{54}$ İkinci olarak, MC sisteminde BM gibi güçlü yetkilerle ve üyelerle donatılmış bir Güvenlik Konseyi’nin olmayışı, dönemin devletlerini MC Misakı’na aykırı davranmaya sevk etmiş olabilir.

49 Laurence R. Helfer, “Exiting Treaties”, Virginia Law Review, Cilt 91 No.7, 2005, s.1621.

50 Ibid.

51 BM üyeliğinden çekilmeye dair tek somut örnek Endonezya vakası olsa da ABD ve Filipinler gibi devletlerin üst düzey yetkililerinin üyelikten çekilmeye dair beyan ve çıkışları, bize muhtemel bir üyelikten çekilme hadisesinde üye devletlerin üyelikten çekilme için başvurabilecekleri dayanaklar hakkında fikir vermektedir diyebiliriz.

52 Cliff Sims, "In the wake of Brexit, Alabama congressman wants U.S. to exit U.N.", Yellow Hammer, 26 Haziran 2016, https://yellowhammernews.com/wake-brexit-alabama-congressman-wants-u-s-leave-u-n/ (Erişim Tarihi 23 Ocak 2018). Ayrıca, ABD, hem maddi nedenleri hem de Filistin politikaları nedeniyle, UNESCO üyeliğinden çekilme sürecini başlattığına dair bkz. Eli Rosenberg ve Carol Morello, "U.S. Withdraws from UNESCO, the U.N.s Cultural Organization, Citing Anti-Israel Bias", The Washington Post, 12 Ekim 2017, https://www.washingtonpost.com/ news/post-nation/wp/2017/10/12/u-s-withdraws-from-unesco-the-u-n-s-cultural-organization-citing-anti-israelbias/?noredirect=on\&utm_term=.61694c18f02f (Erişim Tarihi 23 Ocak 2018).

53 Ancak, Filipinler Başkanı Duterte, daha sonra sözlerinin yanlış anlaşıldığını iddia etmiş ve BM üyeliğinden çekilme niyetlerinin olmadığını belirtmiştir. Bloomberg, "Duterte Threatens to Withdraw Philippines from UN, Hits US", The Associated Press, 21 Ağustos 2016, https://www.bloomberg.com/news/articles/2016-08-21/duterte-threatensto-withdraw-philippines-from-un-hits-us (Erişim Tarihi 02 Eylül 2016). Ayrıca, Filipinler'in Uluslararası Ceza Mahkemesi'nden ayrılışı için bkz. Asia Pasific Report, "ICC Withdrawal 'a principled stand', Claims Philippines' Foreign Secretary”, Pacific Media Watch, 15 Mart 2018, https://asiapacificreport.nz/2018/03/15/icc-withdrawal-a-principledstand-claims-philippines-foreign-secretary/ (Erişim Tarihi 25 Mart 2018).

54 Malcolm N. Shaw, International Law, Cambridge University Press, Cambridge, 2008, s.5. 
Netice itibariyle, yukarıda değinildiği gibi, BMüyeliğinden çekilmeye dair incelemiş olduğumuz enstrümanlar olan hazırlık çalışmaları, Endonezya örneği ve VAHS konuya ilişkin aydınlatıcı bir prosedür sunmaktan uzaktır. Sadece, VAHS 62. maddesinde kodifiye edilmiş uluslararası teamül olan rebus sic stantibus ilkesi BM üyeliğinde çekilmek için başvurulabilecek bir araç olarak karşımıza çıssa da, uygulanabilirliği zor görünmektedir. Bu anlamda ve mevcut şartlarda, her ne kadar rebus sic stantibus BM üyesi bir devlet için tek yol gibi görünse de duruma göre bu ilkenin şartları oluşmaksızın da herhangi bir üye devletin üyelikten çekilme başvurusu yapıp, sonuç alabileceği söylenebilir.

Eğer amaç bir üye devletin üyelikten çekilmesini güçleştirmekse bunu bir düzenleme ile daha belirgin hale getirmek mümkündür. Mesela, üyelikten çekilmeyi Güvenlik Konseyi daimi üyelerinin olumsuz oy kullanmaması şartına bağlamak süreci yeterince zorlaştıracaktır. Böyle bir uygulama devletlerin egemenlik yetkileri açısından sorunlu görülebilir. Nitekim konu San Francisco Konferansı'nda tartışılırken, bazı delegeler üyelikten çekilme hakkının bir egemenlik ifadesi olduğunu ileri sürerek, üyelikten çekilme konusunun herhangi bir düzenleme ile sınırlandırmasına itiraz etmişlerdir. ${ }^{55}$ Ancak Kelsen'in de belirttiği gibi, sınırlandırılmamış egemenlik yaklaşımı esas alındığında, devletlerin bir örgüt üyeliğine devam etmeleri ilgili örgütten memnun kalıp kalmadıkları gibi bir soyut kıstasa bağlı olacaktır. Oysaki bir sözleşme ile kurulmuş olan herhangi bir uluslararası örgütün, üyelerinin egemenliklerinde kısıtlayıcı bir işleve sahip olabileceği göz ardı edilmez bir durumdur. ${ }^{56} \mathrm{Bu}$ nedenle örgütün mahiyetine göre üyelikten çekilme hakkının başvurulamaz bir yönteme bağlanması yerine bu hakkın kullanılmanı mümkün kılabilecek belli ve makul şartlara bağlanması devletlerin egemenlik yetkileri açısından bir sorun olmayacak, aksine keyfi uygulamaları önleyecek ve belirsizliklerin oluşmasının önüne geçecektir. ${ }^{57}$

Diğer taraftan, mevcut haliyle BM Şartı, üyelikten çekilme sürecini zorlaştırmaktan ziyade belirsiz hale getirmekte ve keyfi yorumlamalara müsait kılmaktadır. Bu bağlamda, BM Şartı́ndaki bu eksik düzenlemenin giderilmesi için şu tavsiyede bulunabiliriz: Konunun Genel Kurul'da ele alınarak bir düzenleme yapılması, eğer bir sonuca ulaşılamazsa, Genel Kurul tarafından konunun UAD’a gönderilip alınacak tavsiye görüşü esas alınarak bir düzenleme yapılması. Diğer taraftan, böyle bir düzenlemenin gerçekleşmesi bazı üye devletlerin sıcak bakmamasından dolayı zor görünmektedir. Bilhassa Amerika Birleşik Devletleri ve Rusya gibi bazı ülkeler, Komisyon'da sergiledikleri tutumlara benzer şekilde, üyelikten çekilmenin bir düzenleme ile sarih bir şekilde zorlaştırılmasını,

55 Birleşmiş Milletler San Francisco Konferansı (UNCIO), "Verbatim Minutes of the Ninth Plenary Session”,1945, Doc. 1210, s.20.

56 Kelsen, "Withdrawal from the United Nations", s.33.

57 Uluslarüstü özelliğe haiz bir örgüt olan Avrupa Birliği’nin (AB) kurucu andlaşması da üyelikten çekilme, çıkarılma veya üyeliğin askıya alınmasına dair bir düzenleme içermemekteydi. Bu yönde bir düzenleme ancak 2009 yılında yapılabilmiştir. Ancak şunu da belirtmek gerekir ki, bu tarihten önceki dönemde, fiiliyatta üyelikten çekilme zor olsa bile imkânsız bir durum da değildi. Zira genel kabul gören görüş, devletlerin egemenlik hakları gereği uluslararası yükümlülüklerden cayma haklarının olduğu yönündeydi. Bununla birlikte, mevzuatta bu yönde bir düzenlemenin olmadığı dönemde gerçekleşmiş somut bir üyelikten çekilme vakasının olmadığını da hatırlatmak gerekir. Egemenlik temelinde benzer tartışmalar yürütülüyor olmasına karşın, $\mathrm{AB}$ hem yapısı hem de işleyişi bakımından BM'den çok farklı bir yapıya sahiptir. Bu nedenle üyelikten çekilmenin söz konusu örgütler açısından farklı neticeleri olacaktır. Bilindiği üzere AB'ye üye devletler, BM'ye üye devletlere nazaran çok daha fazla konu ve alanda egemenlik devrinde bulunmuş durumdadırlar. Salt bu durum göz önünde bulundurulduğunda dahi, üyelikten ayrılma konusunun $A B$ açısından çok daha karmaşık sonuçları olacağı açıktır. 2016 yılında gerçekleştirilen referandumla $A B$ üyeliğinden çekilme kararı alan Birleşik Krallık örneği bize bu konuda önemli ipuçları sunmaktadır. Bkz Kamuran Reçber, Avrupa Birliği Hukuku ve Temel Metinleri, Dora Yay., 2018, s.97; Phoebus Athanassiou, "Withdrawal and Expulsion from the EU and EMU Some Reflections”, Legal Working Paper Series, No.10, 2009, s.8; Ian Hurd, International Organizations: Politics, Law, Practice, Cambridge University Press, Cambridge, 2014, s.10. 
egemenliklerinin kısıtlanması olarak görüp buna karşı durabilirler. Örgüt'ün yetmiş yılı aşkın süredir konuya ilişkin herhangi bir düzenleme teşebbüsünde bulunmaması, kuruluş tarihinden itibaren sadece Endonezya örneği gibi tek bir gerçek üyelikten çekilmeye teşebbüs vakası yaşamış olmasına bağlanabilir. Diğer bir deyişle, Örgüt'ün üyelikten çekilme vakalarını gündem yapacak düzeyde buna ihtiyaç duymaması diyebiliriz. Ancak, üyelikten çekilme vakalarının yaşanması durumunda, mevcut BM Şartı’nın ve diğer uluslararası hukuk kaynaklarının yetersiz kalacağı da aşikârdır. İtalyan temsilcinin de Endonezya’nın üyelikten çekilme kararına yaptığı değerlendirmede belirttiği gibi; umulur ki en kısa zamanda, BM üyeliğinden çekilme konusuna açıklık getiren bir düzenleme yapılır. 